\title{
Deltas: a new classification expanding Bates's concepts
}

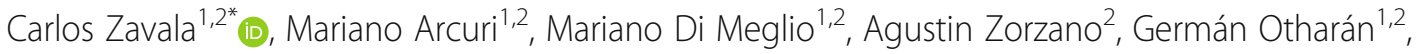 \\ Ainara Irastorza ${ }^{1,3}$ and Antonela Torresi $i^{1,3}$
}

\begin{abstract}
Deltas constitute complex depositional systems formed when a land-derived gravity-flow (carrying water and sediments) discharges into a marine or lacustrine standing body of water. However, the complexity of deltaic sedimentary environments has been oversimplified by geoscientists over the years, considering just littoral deltas as the unique possible type of delta in natural systems. Nevertheless, a rational analysis suggests that deltas can be much more complex. In fact, the characteristics of deltaic deposits will depend on a complex interplay between the bulk density of the incoming flow and the salinity of the receiving water body. This paper explores the natural conditions of deltaic sedimentation according to different density contrasts. The rational analysis of deltaic systems allows to recognize three main fields for deltaic sedimentation, corresponding to (1) hypopycnal (2) homopycnal and (3) hyperpycnal delta settings. The hypopycnal delta field represents the situation when the bulk density of the incoming flow is lower than the density of the water in the basin. According to the salinity of the receiving water body, three different types of hypopycnal littoral deltas are recognized: hypersaline littoral deltas (HSLD), marine littoral deltas (MLD), and brackish littoral deltas (BLD). The basin salinity will determine the capacity of the delta for producing effective buoyant plumes, and consequently the characteristics and extension of prodelta deposits. Homopycnal littoral deltas (HOLD) form when the density of the incoming flow is roughly similar to the density of the water in the receiving basin. This situation is typical of clean bedload-dominated rivers entering freshwater lakes. Delta front deposits are dominated by sediment avalanches. Typical fallout prodelta deposits are absent or poorly developed since no buoyant plumes are generated. Hyperpycnal deltas form when the bulk density of the incoming flow is higher than the density of the water in the receiving basin. The interaction between flow type, flow density (due to the concentration of suspended sediments) and basin salinity defines three types of deltas, corresponding to hyperpycnal littoral deltas (HLD), hyperpycnal subaqueous deltas (HSD), and hyperpycnal fan deltas (HFD). Hyperpycnal littoral deltas are low-gradient shallow-water deltas formed when dirty rivers enter into brackish or normal-salinity marine basins, typically in wave or tide-dominated epicontinental seas or brackish lakes. Hyperpycnal subaqueous deltas represent the most common type of hyperpycnal delta, with channels and lobes generated in marine and lacustrine settings during long-lasting sediment-laden river-flood discharges. Finally, hyperpycnal fan deltas are subaqueous delta systems generated on high-gradient lacustrine or marine settings by episodic high-density fluvial discharges.
\end{abstract}

Keywords: Deltas, Hyperpycnal flows, Homopycnal flows, Hypopycnal flows, Hyperpycnites, Turbidites, Sediment gravity flows, Gravity flows

\footnotetext{
* Correspondence: czavala@uns.edu.ar

'Dpto. de Geología, Universidad Nacional del Sur (UNS), Bahía Blanca, Argentina

${ }^{2}$ GCS Argentina SRL, Molina Campos 150, 8000 Bahía Blanca, Argentina

Full list of author information is available at the end of the article
}

Springer Open (c) The Author(s). 2021 Open Access This article is licensed under a Creative Commons Attribution 4.0 International License, which permits use, sharing, adaptation, distribution and reproduction in any medium or format, as long as you give appropriate credit to the original author(s) and the source, provide a link to the Creative Commons licence, and indicate if changes were made. The images or other third party material in this article are included in the article's Creative Commons licence, unless indicated otherwise in a credit line to the material. If material is not included in the article's Creative Commons licence and your intended use is not permitted by statutory regulation or exceeds the permitted use, you will need to obtain permission directly from the copyright holder. To view a copy of this licence, visit http://creativecommons.org/licenses/by/4.0/. 


\section{Introduction}

Deltas constitute primary depositional elements developed when a land-generated gravity flow (transfer zone) carrying water and sediments reaches a marine or lacustrine standing body of water (depositional zone). Barrell (1912) defined a delta as the deposit, partly subaerial, built by a river into or against a permanent body of water.

Early detailed studies carried out by Fisk (1944), Fisk et al. (1954), Coleman and Gagliano (1965) on the Mississippi delta and other recent deltas (Fisher et al. 1969; Coleman and Wright 1975) deeply influenced the current paradigm of deltaic sedimentation. According to Elliot (1986) "deltas are discrete shoreline protuberances formed where rivers enter oceans, semi-enclosed seas, lakes or lagoons and supply sediment more rapidly than it can be redistributed by basinal processes". Deposition at coastal areas occurs when a fluvial discharge rapidly loses its flow capacity and competence at the river mouth, due to the combined effect of a decrease in flow velocity and confinement. As a result, fluvial sediments transported by shear forces (bedload) accumulate in coastal areas. Once accumulated, these deltaic deposits can be severely affected by basin diffusion processes (reworking) resulting in wave or tide dominated deltas (Galloway 1975). These simple concepts of (littoral) delta building have dominated the geological paradigm for decades, at the point that for most geologists (and textbooks) littoral deltas are considered the only possible type of deltas in nature (as an example, see the review by Miall 1984). Although these depositional concepts are essentially valid, they represent just a narrow view of deltaic sedimentation. Broadly speaking, the present significance of deltaic deposition largely exceeds that of the first so-called deltas (a term coined by the Greek historian Herodotus $450 \mathrm{yr}$ B.C. for the littoral Nile delta plain) according to their similar shape respect to the Greek letter $\Delta$. Bates (1953) made a fundamental contribution applying the jet flow theory on deltaic sedimentation. According to Bates (1953) a delta can be defined as a sedimentary deposit built by jet flow into or within a permanent body of water. This rational analysis of deltaic sedimentation extends the concept of deltas to all the deposits directly supplied by rivers (pointsource expanding flows), being littoral or not. In fact, Bates introduced the concept of submarine (subaqueous) deltas for inner basin sediments directly transferred by relatively dense fluvial discharges generated during river floods (hyperpycnal flows generated by stratified jets). Although Bates's classification was proposed more than 60 years ago, it was poorly applied for the understanding of modern and ancient deltaic deposits.
Deltaic deposits have been dominantly described, documented, and analyzed in marine settings. On the contrary, lacustrine (freshwater and brackish) and hypersaline deltas have received not as much attention, especially in textbooks. Depositional models for lacustrine deltas are mostly derived (and adapted) from delta models proposed for littoral marine settings. Controversially, considering the classification of Bates (1953), lacustrine deltas can be largely more variable than marine deltas, since the salinity of lacustrine water bodies can range from freshwater to hypersaline (brine lakes). Additionally, semi-closed epicontinental seas affected by an important runoff often have salinities that are substantially lower with respect to those found in open seas. For example, the Baltic Sea has surface salinities ranging between 7 and 8 PSU (Practical Salinity Units) Westman et al. 1999), this is about five times lower than the average of marine salinity (35 PSU). This paper explores and expands the rational classification of deltas proposed by Bates by considering different scenarios of density contrast between the incoming flow (river discharge) and the water in the reservoir.

\section{Towards a rational classification of deltas and their deposits}

In his seminal paper, Bates (1953) defined three types of deltas according to the density contrast between the bulk density of the incoming river discharge $\left(\rho_{r}\right)$ and the density of the receiving water body $\left(\rho_{w}\right)$ : (i) marine littoral deltas, (ii) lacustrine Gilbert littoral deltas, and (iii) submarine deltas (Fig. 1). Conceptually, these three situations correspond to the three different behaviors for jet flows when the density of the incoming jet is similar or differs from that of the standing body of water, defining pure jets (equal density), buoyant jets (lower density) and stratified jets (higher density).

Marine littoral deltas (Fig. 1a) form when a river discharges a fluid having a lower bulk density than the density of ocean water $\left(\rho_{r}<\rho_{w}\right)$, resulting in the development of a hypopycnal flow. Once entering the sea, coarse-grained sediments transported as bedload are forced to accumulate at coastal areas forming a mouth bar (or delta front). The incoming freshwater, together with fine-grained materials transported in turbulent suspension (mainly silt-clay and eventually plant remains) commonly develop a buoyant jet with an associated buoyant plume, from where sediment fallout contributes to accumulate prodelta deposits.

Gilbert deltas (Fig. 1b) form when a river discharges a fluid having a similar bulk density as the water in the basin $\left(\rho_{r}=\rho_{w}\right)$, corresponding to a homopycnal flow generated by a pure jet flow. The typical situation occurs when a clear-water bedload-dominated fluvial stream enters in a freshwater lake. Because of their similar density, the incoming flow is rapidly mixed with ambient 

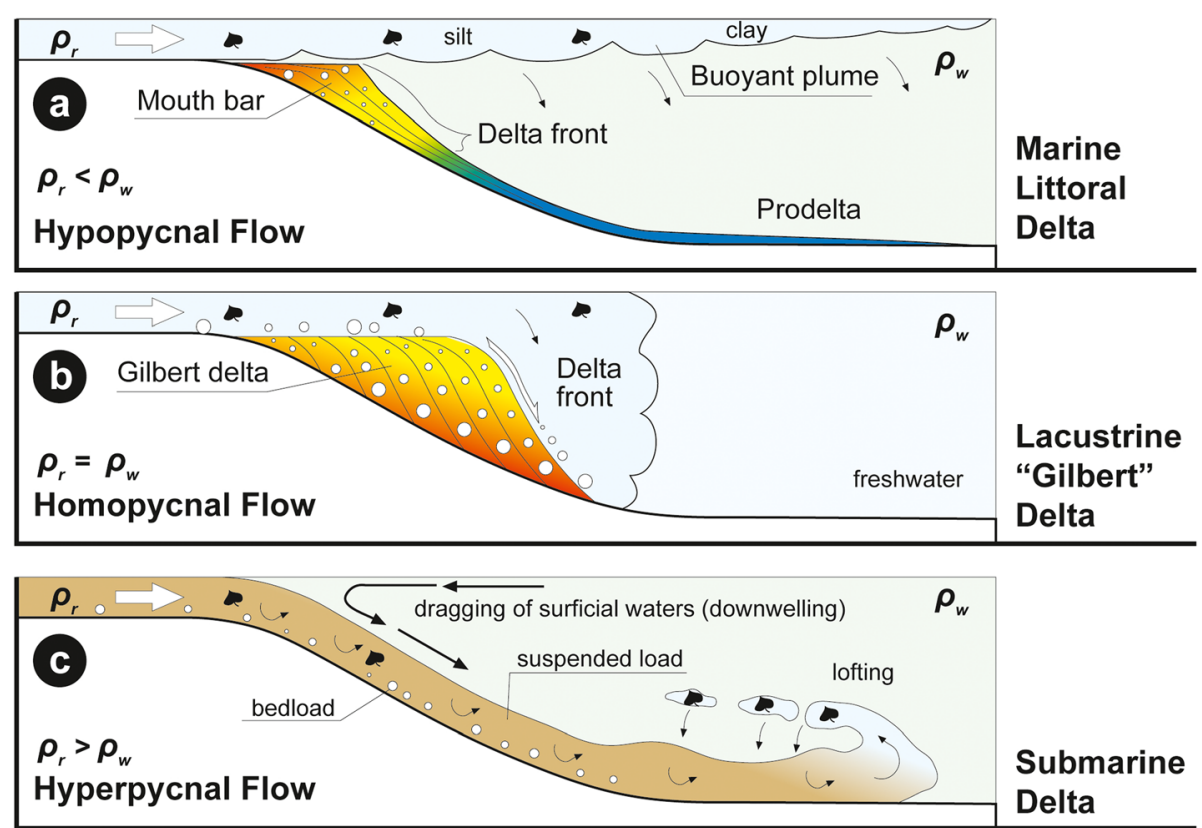

Fig. 1 The three different delta types recognized by Bates (1953) according to the density contrast between the incoming fluid and the receiving water body. a Marine littoral deltas, generated by hypopycnal flows $\left(\rho_{r}<\rho_{w}\right)$. b Lacustrine littoral "Gilbert" deltas, generated by homopycnal flows $\left(\rho_{r}=\rho_{w}\right)$. c Submarine deltas, generated by hyperpycnal flows $\left(\rho_{r}>\rho_{w}\right)$. Modified after Zavala and Pan (2018). $\rho_{r}=$ Bulk density of the river discharge. $\rho_{w}=$ Density of the water in the reservoir

water at the river mouth, resulting in a drastic drop in flow velocity and related flow competence forming a littoral delta. In bedload-dominated rivers, clasts are forced to accumulate in the upper leeside of delta foresets, from where inertia-dominated gravity avalanches develop (Nemec 1990). The results are steep littoral Gilbert deltas (Gilbert 1885), which are very common in proglacial lakes. The development of homopycnal Gilbert deltas in non-freshwater lakes is almost impossible, since it will require to maintain a critical balance of suspended sediment concentration in the fluvial discharge to equal the density of the water in the receiving basin. More recently, the concept of Gilbert deltas has been wrongly extended to steep gravelly fan deltas in marine settings (Postma and Roep 1985; Colella et al. 1987; Breda et al. 2007) which in fact represent coarsegrained marine littoral deltas related to hypopycnal rather than homopycnal conditions.

Finally, submarine deltas form when a river discharges a fluid with a bulk density higher than that of the water in the reservoir $\left(\rho_{r}>\rho_{w}\right)$, resulting in a hyperpycnal flow generated by a stratified jet flow. When this happens, the river flow plunges below the water surface in coastal areas and travels basinward as a land-derived turbidity current. Since river discharges are composed of freshwater, the flow bulk density can be only increased by the excess of load provided by the fine-grained sediments transported in turbulent suspension. According to Mulder and Syvitski (1995), a minimal sediment concentration of $35-45 \mathrm{~kg} \cdot \mathrm{m}^{-3}$ of suspended sediment is required in a fluvial discharge to produce a hyperpycnal plume in normal-salinity marine settings. In the case of freshwater lakes, the required sediment concentration is very low, about $1 \mathrm{~kg} \cdot \mathrm{m}^{-3}$ (Mulder and Syvitski 1995). Hyperpycnal flows have been proved to be also an important contributor to the flux of land-derived organic carbon towards distal, central basin areas (Zavala et al. 2012; Liu et al. 2013; Baudin et al. 2017, 2020).

The three situations outlined by Bates represent just three possible conditions within a continuum. The bulk density of a river discharge can be very variable depending on the size of the drainage network, volume of available sediments, flood magnitude, flow duration and coastal relief (Zavala 2020). Typically, the bulk density of river waters $\left(\rho_{r}\right)$ ranges from $998.20 \mathrm{~kg} . \mathrm{m}^{-3}$ (for sediment-free waters at $20^{\circ} \mathrm{C}$ ) up to more than $2153.20 \mathrm{~kg} \cdot \mathrm{m}^{-3}$ (for a $70 \%$ by volume cohesive debris flow with sediments having a density of $2.65 \mathrm{~g} \cdot \mathrm{cm}^{-3}$, Zavala 2020). On the other hand, the surface density of the receiving water body depends on the water salinity and temperature, ranging from less than 1 PSU (Practical Salinity Units) in freshwater lakes up to more than 300 PSU for concentrated brines. In consequence, the final scenario for deltaic sedimentation will define multiple fields, allowing to understand the origin of deltas and associated deposits from a large more rational point of view. 
Following Bates's concepts and fundamental understanding of jet flows (Fischer et al. 1979; Kim 2001; Hoyal et al. 2003), a new deltaic classification is here proposed (Fig. 2). The X-axis (logarithmic scale) shows the possible range of salinities (in PSU) for lacustrine and marine basins (from freshwater lakes to brines close to saturation) and the range of water densities $\left(\rho_{w}\right)$ considering an averaged marine salt composition at $20^{\circ} \mathrm{C}$. Water densities have been calculated using the Oceanlife Water Salinity Converter (2017). The common range of normal sea surface salinity is also indicated (from 30 to 40 PSU according to the Aquarius mission, NASA). The $\mathrm{Y}$-axis (logarithmic scale) shows the density flows produced by natural river discharges (Zavala 2020), their corresponding sediment concentrations (in $\mathrm{kg} \cdot \mathrm{m}^{-3}$ ) and the bulk density of the flow $\left(\rho_{r}\right.$, considering a $20^{\circ} \mathrm{C}$ interstitial freshwater and a sediment density of 2.65 g. $\left.\mathrm{cm}^{-3}\right)$. The interaction of these two density parameters defines three main fields for deltaic sedimentation (hypopycnal, homopycnal and hyperpycnal delta fields) and a total of seven different delta types. Some selected examples of recent and ancient deltaic deposits classified according to these categories are shown in Tables 1 and 2.

\subsection{Hypopycnal delta field}

The hypopycnal delta field represents the situation when the bulk density of the incoming flow $\left(\rho_{r}\right)$ is lower than the density of the water in the reservoir $\left(\rho_{w}\right)$. All hypopycnal deltas constitute constructive littoral forms since the incoming subaerial flow is forced to stop at coastal areas. This results in the immediate accumulation at the shoreline of all sediments transported by the river as bedload, forming a mouth bar (also referred to as delta front). The characteristics of these mouth bar deposits will depend on the grain size of the sediments transported in bedload and on the interaction with coastal diffusion processes (Galloway 1975). The forced accumulation at the delta front often results in an unbalanced deposition and steep delta slopes, typically affected by gravity avalanches (Rajchl et al. 2008). In coarse-grained systems, these steep high-gradient deltas (especially in fiords) have been wrongly termed as

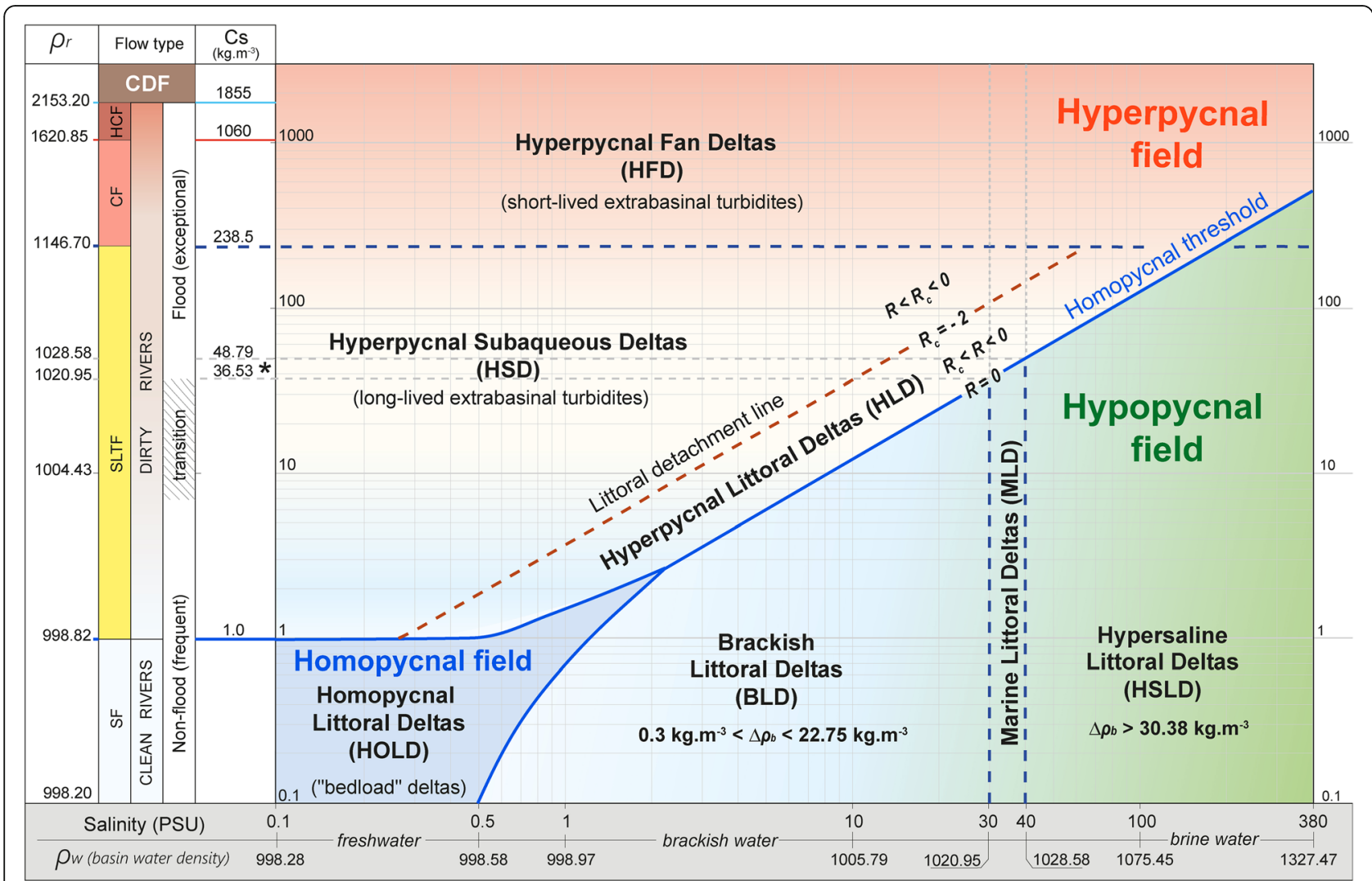

Fig. 2 New proposed classification of deltas following Bates's concepts of density contrast between the incoming flow and the water in the receiving basin. Three main delta fields are recognized, corresponding to hypopycnal, homopycnal and hyperpycnal. The hypopycnal delta field comprises brackish, marine and hypersaline littoral deltas. The homopycnal delta field includes homopycnal littoral deltas. Finally, the hyperpycnal delta field is integrated by hyperpycnal littoral deltas, hyperpycnal subaqueous deltas, and hyperpycnal fan deltas. $\Delta \rho_{b}$ : Differential buoyancy. $R=$ non-dimensional density parameter. $R_{c}=$ critical value for a non-dimensional density parameter. ${ }^{*}$ Critical range of necessary sediment concentration to produce a hyperpycnal flow in normal-salinity marine waters 
Table 1 Some selected examples of recent deltas classified according to the rational classification proposed in this paper. Note that the same system can be characterized by relatively coeval different delta types

\begin{tabular}{|c|c|c|c|c|c|c|c|c|c|}
\hline \multirow[t]{3}{*}{ River } & \multirow[t]{3}{*}{ Basin } & \multicolumn{7}{|c|}{ Delta types } & \multirow[t]{3}{*}{ References } \\
\hline & & \multicolumn{3}{|c|}{ Hypopycnal deltas } & \multirow[t]{2}{*}{ HOLD } & \multicolumn{3}{|c|}{ Hyperpycnal deltas } & \\
\hline & & HSLD & MLD & $\overline{B L D}$ & & HLD & HSD & HFDL & \\
\hline Amu Darya & Aral Sea (UZ) & $x$ & & & & & & & Conrad et al. 2013 \\
\hline Jordan & Dead Sea (JO) & $x$ & & & & & & & Inbar 1987 \\
\hline Congo & Atlantic Ocean (CD) & & $x$ & & & & $x$ & & $\begin{array}{l}\text { Khripounoff et al. 2003; Zavala and } \\
\text { Arcuri } 2016\end{array}$ \\
\hline Al Batha & Oman Gulf (OM) & & $x$ & & & & $x$ & & Bourget et al. 2010 \\
\hline Amazon & Atlantic Ocean (BR) & & $x$ & & & $x$ & $x$ & & Nittrouer et al. 1986; Flood and Piper 1997 \\
\hline Orinoco & Atlantic Ocean (VE) & & $x$ & & & & $x$ & & $\begin{array}{l}\text { Zavala et al. 2012, Zavala and Arcuri 2016; } \\
\text { Deville et al. } 2015\end{array}$ \\
\hline Salado & Pacific Ocean (CL) & & $x$ & & & & & $x$ & Wilcox et al. 2016 \\
\hline Bonea & Tyrrhenian Sea (IT) & & $x$ & & & & & $x$ & Violante 2009 \\
\hline Dragone & Tyrrhenian Sea (IT) & & $x$ & & & & & $x$ & Violante et al. 2016 \\
\hline Gaoping & $\begin{array}{l}\text { Northern South China } \\
\text { Sea (TW) }\end{array}$ & & & & & & $x$ & $x$ & Liu et al. 2013 \\
\hline Parana & Rio de la Plata (AR) & & & $x$ & & $x$ & & & Marcomini et al. 2018 \\
\hline Volga & Caspian Sea (RU) & & & $x$ & & $x$ & & & Overeem et al. 2003 \\
\hline Danube & Black Sea (RO) & & & $x$ & & $x$ & $x$ & & Panin et al. 2016 \\
\hline Yangtze & East China Sea (CN) & & $x$ & & & $x$ & & & Luo et al. 2017 \\
\hline Huanghe & Bohai Sea (CN) & & $x$ & & & $x$ & & & Yang and Liu 2007; Gao et al. 2014, 2018 \\
\hline Ganges- Brahmaputra & $\begin{array}{l}\text { Bay of Bengal. Bengal } \\
\text { Fan (BD) }\end{array}$ & & $x$ & & & $x$ & $x$ & & $\begin{array}{l}\text { Kuehl et al. 1997; Curray et al. 2002; } \\
\text { Lee et al. } 2019\end{array}$ \\
\hline Las Dunas & Gral. Carrera Lake $(\mathrm{CL})$ & & & & $x$ & & & & Bell 2009 \\
\hline Peyto & Peyto Lake (CA) & & & & $x$ & & & & Smith and Jol 1997 \\
\hline
\end{tabular}

CD - Congo, OM - Oman, BR - Brazil, VE - Venezuela, CN - China, CL - Chile, IT - Italia, TW - Taiwan, China AR - Argentina, RU - Russia, RO - Romania, CA - Canada, JO - Jordan, KR - Korea, BD - Bangladesh, UZ - Uzbekistan

Table 2 Some selected examples of ancient deltas classified according to the rational classification proposed in this paper. Note that the same system can be characterized by relatively coeval different delta types

\begin{tabular}{|c|c|c|c|c|c|c|c|c|c|}
\hline \multirow[t]{3}{*}{ Unit } & \multirow[t]{3}{*}{ Basin } & \multicolumn{7}{|c|}{ Delta types } & \multirow[t]{3}{*}{ References } \\
\hline & & \multicolumn{3}{|c|}{ Hypopycnal deltas } & \multirow[t]{2}{*}{ HOLD } & \multicolumn{3}{|c|}{ Hyperpycnal deltas } & \\
\hline & & BLD & MLD & $\overline{H S L D}$ & & HLD & HSD & HFDL & \\
\hline Agrio & Neuquén (AR) & $x$ & & & & $x$ & $x$ & & Irastorza et al. 2018 \\
\hline Duvengan & Western Canadian (CA) & $x$ & & & & $x$ & & & Bhattacharya and MacEachern 2009 \\
\hline Ferron SS. & Cretaceous Seaway (US) & $x$ & & & & $x$ & & & Bhattacharya and MacEachern 2009 \\
\hline Yanchang & Ordos (CN) & $x$ & & & $x$ & $x$ & $x$ & & Zavala et al. in press \\
\hline Lajas - Los Molles & Neuquén (AR) & $x$ & $x$ & & & $x$ & $x$ & & Paim et al. 2011 \\
\hline Mayaro & Columbus (TT) & & $x$ & & & & $x$ & & Zavala and Arcuri 2016 \\
\hline Achimov & West Siberia (RU) & & & & & & $x$ & & Zavala 2020 \\
\hline Guarico & Guarico (VE) & & $x$ & & & & $x$ & $x$ & Zavala 2020 \\
\hline Rayoso & Neuquén (AR) & & & $x$ & & $x$ & $x$ & & Zavala et al. 2006 \\
\hline Coalmont & North Park (US) & & & & $x$ & & & & Flores 1990 \\
\hline Vikulovo & West Siberia (RU) & & & & & $x$ & & & Zavala et al. 2016 \\
\hline Leushinska & West Siberia (RU) & & & & & $x$ & & & Zavala et al. 2016 \\
\hline
\end{tabular}

VE - Venezuela, CN - China, AR - Argentina, RU - Russia, CA - Canada, TT - Trinidad and Tobago, US - United States 
"Gilbert deltas" based on the existence of large-scale foresets (Nemec 1990). In fact, the term Gilbert deltas should be restricted to deltas originated by homopycnal flows.

An important constituent of hypopycnal deltas is the prodelta. The prodelta is mainly composed of finegrained materials carried as suspended load in the fluvial discharge, which are transported basinward by buoyant jets and related buoyant plumes. The capacity of suspended load sediments to travel basinward in coastal buoyant plumes will depend on the volume and grainsize of the sediment, and on the differential buoyancy $\left(\Delta \rho_{b}\right)$ provided by the negative density contrast between the incoming river water $\left(\rho_{r w}\right)$ and the water in the receiving basin $\left(\rho_{w}\right)$. The differential buoyancy $\Delta \rho_{b}$ is an indication of the suspended sediment load (in kg. $\mathrm{m}^{-3}$ ) that the buoyant plume can sustain, and is calculated as follows:

$$
\Delta \rho_{b}=\rho_{w}-\rho_{r w}
$$

where $\rho_{w}$ is the density of water in the receiving basin, and $\rho_{r w}$ is the density of water (typically freshwater) in the fluvial discharge. The $\Delta \rho_{b}$ is critical for the development (or not) of extensive sediment-laden buoyant plumes, which will effectively control the extension and characteristics of the associated prodelta deposits. The collapse of buoyant plume sediments has been recognized as an alternative origin of intrabasinal turbidites (Parsons et al. 2001; Zavala and Arcuri 2016; Hage et al. 2019).

A common characteristic of all hypopycnal littoral delta deposits is the accumulation of progradational $\mathrm{m}$ thick coarsening- and thickening-upward successions (Coleman and Prior 1982; Allen and Mercier 1987; Gani and Bhattacharya 2005; Bhattacharya and MacEachern 2009). The characteristics and geometry (depositional slope) of delta-front and prodelta deposits will depend on the basin physiography, magnitude and duration of the associated discharge, grain size of the river-supplied sediments, basin diffusion processes, and $\Delta \rho_{b}$. According to the magnitude of the differential buoyancy, three categories of hypopycnal deltas are here recognized (Figs. 2 and 3): (i) Hypersaline littoral deltas (HSLD), (ii) Marine littoral deltas (MLD) and (iii) Brackish littoral deltas (BLD).

Hypersaline littoral deltas (HSLD) are commonly associated with underfilled hypersaline lakes and closed hypersaline seas (Figs. 2 and 3a, Tables 1 and 2). These deltas are rare, since one of the characteristics of hypersaline basins is a negative water balance (associated with a low runoff) that favors salt concentration. These deltas have a high $\Delta \rho_{b}$ (typically higher than $30.38 \mathrm{~kg} \cdot \mathrm{m}^{-3}$ ) allowing the development of extensive buoyant jets and plumes that can transport relatively coarse-grained suspended materials (fine-grained sands). The ability to transport these materials along the plume will depend on how far the buoyant jet flow can be maintained. Lower delta front and prodelta deposits are dominated by sediments accumulated by fallout processes, resulting in very gentle delta slopes (Fig. 3a).

Marine littoral deltas (MLD) (Fig. 1a, see also Figs. 2 and $3 \mathrm{~b}$, Tables 1 and 2 ) are the best-known type of littoral deltas. These deltas have been classified by Galloway (1975) according to the dominant marine diffusion process recognized in coastal areas, including fluvialdominated, wave-dominated, and tide-dominated deltas. This classification was later complemented by Orton and Reading (1993), who added the overall grain-size of the sediments. The high-density contrast between marine waters and incoming freshwater results in a $\Delta \rho_{b}$ ranging between 22.75 and $30.38 \mathrm{~kg} . \mathrm{m}^{-3}$. In consequence, silt and clay materials (and even plant debris) transported as suspended load often form part of buoyant plumes. The collapse of these sediments (through flocculation and suspension fallout "rain") results in the accumulation of well-developed laminated and graded prodelta deposits (Nemec 1995). Due to the small volume and grain-size of the sediments carried in the buoyant plume, the slope of the delta front-prodelta in MLD tends to be steeper than in HSLD.

Brackish littoral deltas (BLD) are commonly developed in underfilled/balanced filled lakes and partially closed (inland or epicontinental) marine basins with reduced salinity due to an important influx of freshwater (Figs. 2 and 3c, see also Tables 1 and 2). In brackish littoral deltas the $\Delta \rho_{b}$ is low (typically ranging between 0.3 and $22.75 \mathrm{kgm}^{-3}$ ), resulting in weak and diluted buoyant plumes. If fine-grained sand and silts cannot be supported within the buoyant plume, prodelta deposits will be poorly developed and dominantly composed of clay and plant debris. In contrast, sandy suspended sediments can be forced to accumulate at the lower delta front by an interaction of traction-plus-fallout processes that typically generate massive, laminated or climbing rippled sandstones. This unbalanced sedimentation often results in steep delta front deposits subject to frequent sediment avalanches. Brackish littoral deltas are very sensitive to variations in the bulk density of the river discharge. The incoming flow can easily go hyperpycnal if the sediment concentration increases seasonally, thus transforming BLD into hyperpycnal (ramp) littoral deltas.

\subsection{Homopycnal delta field}

In the homopycnal delta field the bulk density of the incoming flow is similar respect to that of the water in the receiving basin (Figs. 2 and 3d, see also Tables 1 and 2). 


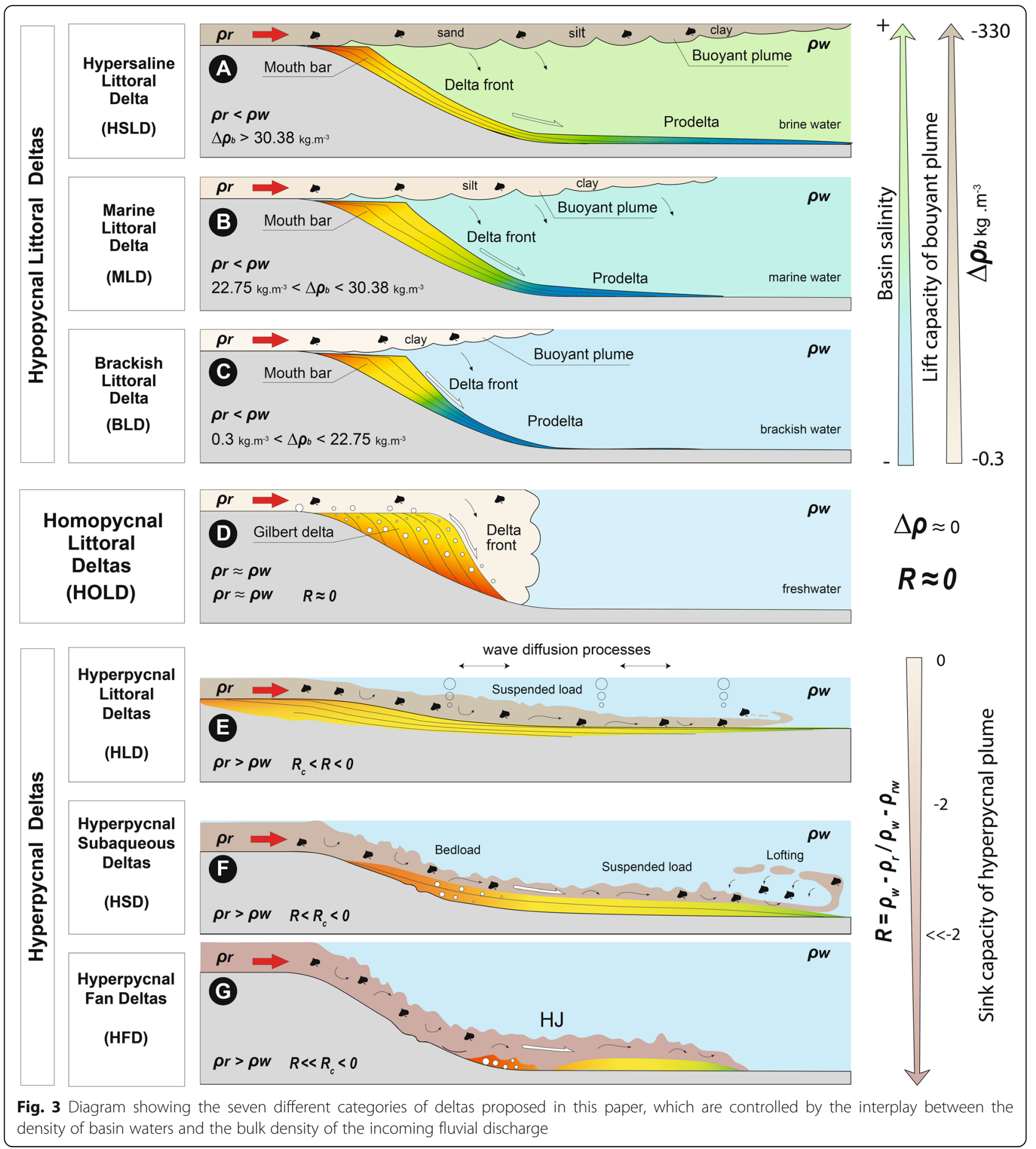

This condition restricts the existence of homopycnal littoral deltas (HOLD) to clear bedload-dominated rivers entering freshwater lakes (Bates 1953). Bedload sediments are transported by shear forces at the base of the streamflow until reaching the river mouth. At this point the flow slows down and the bedload is forced to accumulate at the upper delta front. This unbalanced sedimentation results in the periodical collapse of accumulated sediments in a series of gravitational avalanches produced when the critical depositional slope angle is exceeded at the upper delta front (Winsemann et al. 2018). The characteristics of homopycnal deltas will depend on the grain size of the associated bedload and the critical slope to produce a gravity instability at the depositional slope. Sediment avalanches in the delta front are essentially inertia flows, where the coarsest- 
grained sediments travel at the front of the flow (Nemec 1990). Consequently, homopycnal delta deposits are the only littoral delta accumulations capable of building fining-upward successions (Flores 1990). Fine-grained fallout-generated prodelta deposits, very common in hypopycnal deltas, are absent in HOLD, since these deltas lack of buoyant plumes. The better-known examples of HOLD are Gilbert deltas (Gilbert 1885), which are littoral gravelly deltas developed on proglacial lakes (Tables 1 and 2). The progradation of Gilbert deltas over poorly developed prodelta deposits can result in very high and steep delta foresets.

\subsection{Hyperpycnal delta field}

The hyperpycnal delta field corresponds to the situation when the bulk density of the incoming river flow $\left(\rho_{r}\right)$ is higher than the density of the water in the receiving basin $\left(\rho_{w)}\right.$. The excess of density provided by the suspended load results in a differential sink density $\left(\Delta \rho_{s}\right)$ that allows the flow to sink below basin waters at coastal areas (Mulder and Syvitski 1995; Mulder et al. 2003). This $\Delta \rho_{s}$ is equivalent to the fractional density difference $\left(R_{t}\right.$ or $\left.\Delta \rho / \rho\right)$ used in the analysis of jet flows (Cantelli et al. 2008). The value of this differential density depends on the contrast between the sediment concentration of the incoming flow (typically ranging from sediment laden turbulent flows to cohesive debris flows, Zavala 2020) and the density of the water in the reservoir (Fig. 2). It can be calculated as follows:

$$
\Delta \rho_{s}=\rho_{r}-\rho_{w}
$$

where $\rho_{\mathrm{r}}$ is the bulk density of the fluvial discharge, and $\rho_{\mathrm{w}}$ is the density of water in the receiving basin. The $\Delta \rho_{\mathrm{s}}$ represents the relative load of the incoming flow, and potentially controls the effectiveness of shear forces and finally the erosional capacity of stratified jet flows associated with hyperpycnal discharges. In stratified jets (with a high bulk density respect to the ambient water), composed of a light interstitial fluid with an excess of load provided by suspended particles, the settling of the suspended load can result in a flow density reversal or "lofting" (Simpson 1982; Sparks et al. 1993; Zavala et al. 2008; Pritchard and Gladstone 2009). The density contrast between the incoming jet flow and the receiving water body was discussed by Turner and Huppert (1992) and Kim (2001), who introduced a non-dimensional density parameter $R$. The rheological significance of this parameter is similar respect to the $\Delta \rho_{\mathrm{s}}$ since it provides an indication of the relative load of the incoming flow. The main difference resides in that the $R$ parameter is non-dimensional and takes into consideration the buoyant effect of the incoming freshwater contained in the fluvial discharge. The density parameter $R$ is expressed as:

$$
R=\frac{\rho_{w}-\rho_{r}}{\rho_{w}-\rho_{r w}}
$$

where $\rho_{w}$ is the density of water in the receiving basin, $\rho_{r}$ is the bulk density of the fluvial discharge, and $\rho_{r w}$ is the density of the water in the fluvial discharge. In sediment-laden jets $R<0$. In this situation, a critical value $R_{c}$ was proposed, which separates weak plunging jets $\left(R_{c}<R<0\right)$ from strong plunging jets $\left(R<R_{c}<0\right)$. In weak plunging jets, the flow originally plunges, but the density difference between the incoming flow and the reservoir water is not enough to produce a substantial shear and erosion at the flow bottom. This small density contrast makes the suspended cloud easy to be maintained by normal marine diffusion processes (like tides, waves, and ocean currents). On the contrary, strong plunging jets are heavier and interact with the flow bottom as a land-generated density current (or extrabasinal turbidite), capable of eroding the basin floor and transfer the sediments farther basinward with a system of subaqueous channels and lobes. The critical value $R_{c}$ was estimated to be -2.0 after a series of flume experiments performed by Kim (2001).

According to the non-dimensional density parameter $R$ (above or below the critical value $R_{c}$ ), basin physiography, and incoming flow rheology, three types of hyperpycnal deltas are recognized (Figs. 2 and 3): (i) hyperpycnal littoral deltas (HLD), (ii) hyperpycnal subaqueous deltas (HSD) and (iii) hyperpycnal fan-deltas (HFD).

Hyperpycnal littoral deltas (HLD) are very lowgradient littoral deltas (Fig. 3e). HLD are partially equivalent to ramp deltas (Overeem et al. 2003), prodeltaic shelves (Bhattacharya and MacEachern 2009), muddy prodeltaic hyperpycnites (Wilson and Schieber 2014) and storm-flood-dominated deltas (Lin and Bhattacharya 2020). These deltas form when sediment laden (dirty) rivers enter in brackish (lacustrine or marine) or normal-salinity marine basins. HLD are formed by weak plunging jets (Kim 2001) resulting in light hyperpycnal plumes. These weak plunging jets form when the nondimensional density parameter $R$ is in between 0 and 2. Flume experiments (Kim 2001) show that in these conditions the flow does not have enough weight to interact with the basin bottom (erode), and sediments can be easily maintained in suspension by adding some additional energy, like that provided by tides, waves, or ocean currents. This interaction between weak hyperpycnal flows and the basin dynamic allows fine-grained (sand-silt-clay) sediments to be transported and accumulated very far (typically 100's of $\mathrm{km}$ ) from the river 
mouth (Fig. 4). An example of the interaction between hyperpycnal flows and wave diffusion processes (Fig. 3e) are wave-enhanced hyperpycnal flows (Lamb et al. 2008; Macquaker et al. 2010; Plint 2013; Schieber 2016; Wilson and Schieber 2017). Many HLD form when the discharges of moderate dirty rivers enter in brackish (lacustrine or marine) basins. As pointed out by Mulder and Syvitski (1995), a number of dirty rivers have an average of suspended sediment load between 1 and 40 kg. $\mathrm{m}^{-3}$ during normal (average) annual discharges. In normal-salinity marine waters these "dirty" river discharges commonly result in classical hypopycnal marine littoral deltas (MLD), since the bulk density of the river discharge is commonly below the required threshold to go hyperpycnal. Nevertheless, in brackish basins (Fig. 2) these incoming sediment-laden flows could have enough density to plunge in coastal areas, thus generating a weak hyperpycnal plume. HLD can also develop in normal-salinity marine basins. According to Mulder and Syvitski (1995), it is assumed that a minimal sediment concentration of $35-45 \mathrm{~kg} \cdot \mathrm{m}^{-3}$ of suspended sediment is required in a fluvial discharge to produce a hyperpycnal plume in marine settings. Nevertheless, this minimal concentration is largely below the necessary critical concentration $R_{c}$ required to produce a hyperpycnal subaqueous delta (characterized by channel-lobe complexes) in marine settings. For example, the Yellow River (Huanghe) (Wang et al. 2006; Gao et al. 2014) is considered a hyperpycnal-dominated delta (Gao et al. 2014), but its low average sediment concentration results in a low gradient and progradational HLD. These low density hyperpycnal plumes can be easily deflected by littoral currents (like in the Yangtze delta, Luo et al. 2017). This situation is common to other large river deltas like the Amazon (Nittrouer et al. 1986), Ganges-Brahmaputra (Kuehl et al. 1997), and Han (Cummings et al. 2015) deltas, all characterized by extended (100's of km) lowgradient HLD's. The Han river is considered a moderately dirty river (Mulder and Syvitski 1995), and the interaction between weak hyperpycnal flows and tidal action can explain the very low gradient $(<0.2$ degrees) delta foresets (Cummings et al. 2015), which is typical of HLD's.

Modern and ancient HLD's (see examples in Tables 1 and 2) build up progradational shallow clastic ramps that can extend for 100's of kilometers basinward in brackish lakes, partially closed epicontinental seas, and marine shelves (Gao et al. 2018). In partially closed seas, like the Western Interior Seaway (USA) during the Late Cretaceous, the salinity was substantially lowered due to

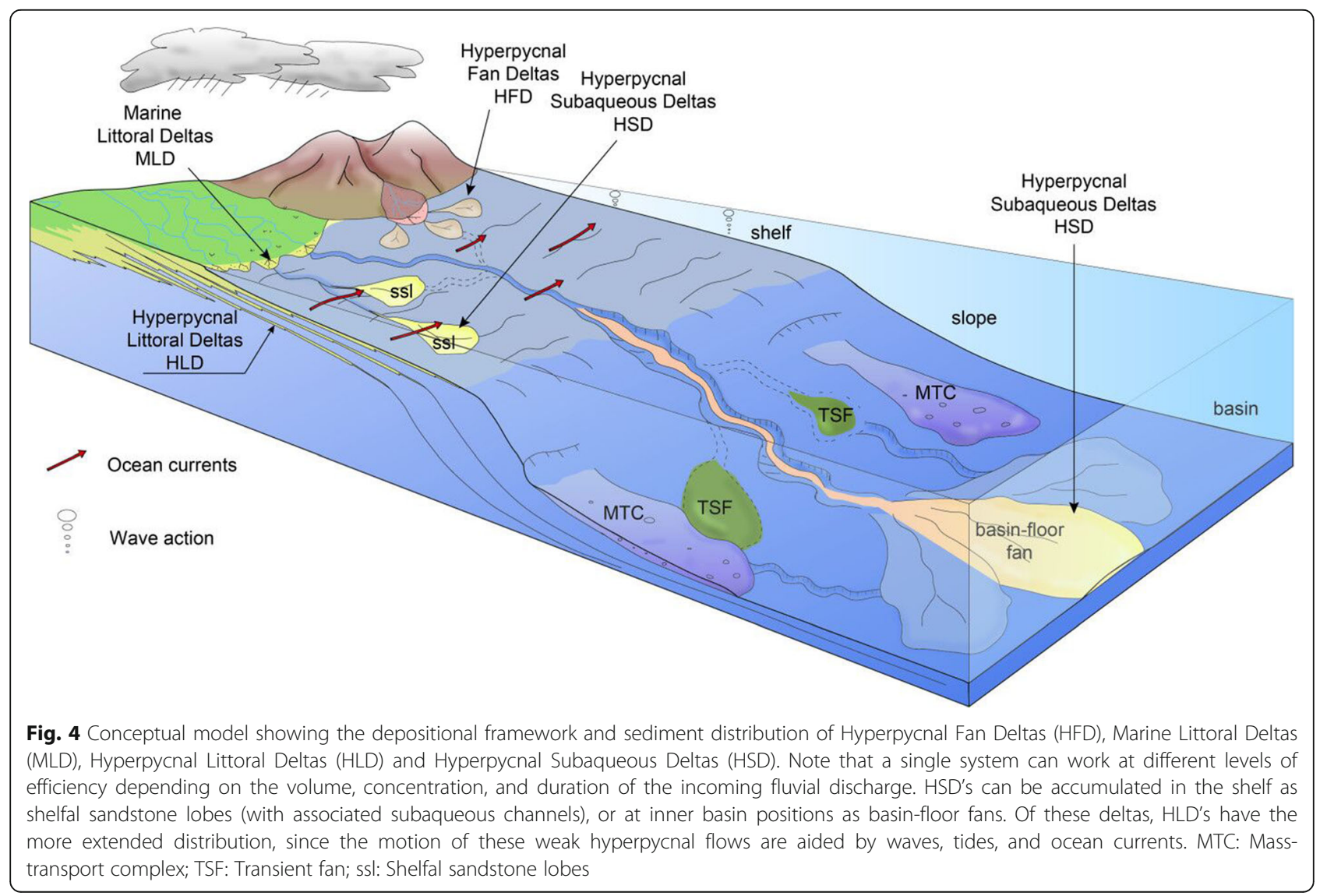


an increasing contribution of riverine runoff. Petersen et al. (2016) estimated a salinity lower than 11 PSU for coastal environments, being lesser than one-third of the average salinity of open seas. In the Lower Cretaceous Agrio Formation (Neuquén Basin, Argentina) HLD deposits conform m-thick wave-dominated coarseningand thickening-upward successions (Irastorza et al. 2018). These packages commonly end up with a regionally extended bioclastic limestone bed. It is interpreted that these changes between progradational cycles and limestones are related to salinity fluctuations. In contrast to hyperpycnal subaqueous deltas (HSD), which are commonly characterized by bedload and suspended load deposits detached from the river mouth (Zavala and Pan 2018), HLD are attached to the shoreline forming littoral deposits accumulated by the collapse of the suspended load (bedload deposits are uncommon). The slope of these littoral deltas is extremely low, typically between 0.2-0.003 degrees (Overeem et al. 2003; Bhattacharya and MacEachern 2009; Wilson and Schieber 2014; Cummings et al. 2015; Gao et al. 2018). The common reworking by wave diffusion processes, the low gradient of the delta front, and the overall progradation shown by HLD's make it possible to wrongly interpret these deltaic deposits as storm-dominated shoreface deposits/strand plains, or either wave-dominated parasequences. If the sediment load of river discharges substantially increases during floods, a $R$ below the critical number of -2 can make these deltas to seasonally evolve into detached hyperpycnal subaqueous deltas.

Hyperpycnal subaqueous deltas (HSD) constitute the most commonly recognized type of hyperpycnal delta (Mutti et al. 1996; Mulder et al. 2003; Mutti et al. 2003; Nakajima 2006; Zavala et al. 2006; Zavala and Arcuri 2016; Zavala and Pan 2018) generated by relatively highdensity flood river discharges in marine and lacustrine basins. To generate a HSD, the incoming fluvial discharge should have a $R$ density parameter below the critical $R_{c}$ of -2 (Figs. 2 and 3f), corresponding to the field of long-lived sediment-laden turbulent flows (SLTF, Zavala 2020). SLTF are pure turbulent flows with a suspended sediment concentration ranging from 1 to 238.5 kg.m ${ }^{-3}$ (Fig. 2; Zavala 2020), this is below the Bagnold's limit (9\% vol) (Bagnold 1962). Due to its relative high bulk density, the river discharge plunges and bypass coastal areas generating a coastal-detached subaqueous channel-lobe system (Zavala and Pan 2018). The associated deposits show the characteristics of extrabasinal turbidites (Zavala and Arcuri 2016). In brackish (lacustrine or marine) settings, the density threshold to generate HSD is easily achieved by most dirty rivers (Fig. 2). In contrast, in normal-salinity seas, the generation of hyperpycnal subaqueous deltas requires a density contrast produced by a suspended sediment concentration much higher than the minimum of $35-45 \mathrm{~kg} \cdot \mathrm{m}^{-3}$ proposed by Mulder and Syvitski (1995). Theoretical concepts and flume experiments (Kim 2001) suggest that the required suspended sediment concentration in the incoming flow to produce a HSD in the ocean should be over $100 \mathrm{~kg} \cdot \mathrm{m}^{-3}$ (Fig. 2). In consequence, hyperpycnal flows produced by dilute hyperpycnal discharges $(<100$ $\mathrm{kg} . \mathrm{m}^{-3}$ ) in normal salinity seas (related to some dirty rivers often affected by coastal diffusion processes, Shanmugam 2018) result in HLD, and cannot be considered as analogs of HSD's. These high-density hyperpycnal discharges are commonly composed of suspended load and can also include a bedload component. Bedload deposits are common in proximal settings, typically characterized by either extrabasinal and/or intrabasinal conglomerates embedded within massive sandstone deposits (Griggs et al. 1970; Zavala et al. 2011). Suspended load deposits are dominantly composed of massive sandstones followed by laminated and ripple-drift cross-laminated sandstones (Zavala et al. 2011). In marine and saline basins, the density reversal induced by the interstitial freshwater of parent flows result in the origin of lofting plumes that lead to the accumulation of lofting rhythmites (Zavala et al. 2008; Zavala and Arcuri 2016). These deposits commonly show abundant plant remains, microfossils and fossil debris eroded from the basin bottom at different water depths (Griggs et al. 1970). HSD are typically associated with medium to large size rivers characterized by long-lived and quasi-steady fluvial discharges (Khripounoff et al. 2003). The continuous pumping of the fluvial discharge allows these flows to travel considerable distances also along near-flat basin bottoms (Bourget et al. 2010). Depending on the duration of the incoming flow and the basin physiography, HSD's can develop on the shelf as channel fills and shelfal sandstone lobes (Mutti et al. 1996), or at inner basin areas as basin-floor fan complexes (Fig. 4). One of the most spectacular examples of a recent HSD corresponds to the Bengal Fan, which is the largest submarine fan on Earth (Table 1). The Bengal Fan (also known as the Ganges Fan) is about $3000 \mathrm{~km}$ long, $1430 \mathrm{~km}$ wide, and have a maximum accumulated thickness of $16.5 \mathrm{~km}$ (Curray et al. 2002). Recently, the International Ocean Discovery Program Expedition 354 (Lee et al. 2019) discovered abundant woody debris in recent extrabasinal turbidites recovered at 3700-m water depth, ca. $2000 \mathrm{~km}$ away from the river mouth. These deposits enhanced the importance of hyperpycnal flows in building very thick subaqueous delta successions as basin-floor fans.

Hyperpycnal fan deltas (HFD) are a special kind of hyperpycnal deltas generated in high gradient settings by small mountainous rivers (Fig. 4). During high-peak floods, these rivers produce short-lived high-density flows (typically concentrated flows, hyperconcentrated 
flows and exceptionally, cohesive debris flows). The high sediment concentration of these flows results in a very low non-dimensional density parameter $R$ (Figs. 2 and $3 \mathrm{~g}$ ) that forces the flow to plunge in coastal areas and to travel basinward as a high-density inertia-dominated flow (Liu et al. 2013). These inertial flows require a slope to maintain their complex internal sediment support mechanism (Zavala 2020), and eventually to transform into more dilute density flows. Due to their short duration, main deposits associated with these flows constitute residual conglomerates and fan-shape lobes accumulated close to the depositional slope break (Prior and Bornhold 1990; Liu et al. 2013). These flows are often affected by multiple flow transformations and hydraulic jumps, losing all original lightweight extrabasinal components. In consequence, the final deposit can resemble those typical of intrabasinal turbidites (Zavala and Arcuri 2016; Zavala 2020).

\section{Deltas and sequence stratigraphy}

The rational analysis of deltaic deposition introduced in this paper demonstrates that deltas are largely more complex than previously considered. The variability observed in the characteristics (concentration, volume, and duration) of incoming fluvial discharges and the location of depositional areas deeply contrasts with the simplified depositional models proposed by the eustasy-driven sequence stratigraphy (Catuneanu et al. 2009). Such sequence-stratigraphic models are oversimplified, as they consider a near constant sediment supply (Jervey 1988) and a primary accumulation of coarse-grained sediments close to the shoreline in littoral deltas and associated coastal systems.

Growing evidence indicate that climatically controlled allocyclic variations along the geological time result in deltas having different efficiency (Fig. 4). The last allows to potentially explain most depositional elements included in sequence stratigraphic models without the need of incorporating long- and short-term sea-level variations.

During highly-efficient periods sediment supply from rivers can be directly transferred to inner basin areas (shelf or base-of-slope) as extrabasinal (hyperpycnal) turbidites, forming HSD's with subaqueous channels and stacked sandstone lobes (Fig. 4) even during Highstand Systems Tract (HST). If this situation is not properly considered, these deposits could be wrongly interpreted as accumulated during a Falling Stage Systems Tract (FSST) or a Lowstand Systems Tract (LST), both related to a forced regression (relative sea-level fall). Additionally, weak hyperpycnal flows generated by dirty rivers combined with basin diffusion processes (waves, tides and ocean currents) can build HSD's, characterized by small-scale progradational sequences that can extend
100 's of km offshore in shallow shelfal areas (Fig. 4). Due to the apparent shallowing upward trend and the common occurrence of wave reworking, these lowgradient delta-front deposits could be misinterpreted as beach of shoreface deposits composing parasequences driven by high-frequency sea level changes accumulated during HST's.

Understanding this climatically-driven sequence stratigraphy is very important also for the study of lacustrine basins, since it provides a new interesting paradigm to give a rational explanation to some unsolved task of eustasy-driven sequence stratigraphy like (1) the origin of third order cycles and depositional sequences, (2) the origin of eustatic sea level falls during hyperthermals, and (3) stratigraphic controls in non-marine sequence stratigraphy.

\section{Conclusions}

The delta classification early proposed by Bates (1953) deeply changed the geological paradigm about the origin of deltaic deposits, from a pure descriptive-geomorphological standpoint towards a rational framework. This novel point of view allows to explain the origin of poorly known river-sourced clastic deposits recognized in shallow to deep-water settings. Understanding the interaction between the bulk density of the river discharge and the density of the receiving body of water is fundamental for defining the different possible scenarios for deltaic deposition. The delta classification here proposed expands the original concept taking into consideration the main depositional controls on deltaic sedimentation. The new proposed classification recognizes seven delta types distributed within three fields of deltaic sedimentation. Although the limits between the different fields and delta types here proposed are well defined, the controlling parameters can be highly variable. As an example, the salinity of the receiving water body can be substantially lowered at the river mouth due to the continuous supply of freshwater (Parsons et al. 2001; Zavala and Arcuri 2016; Hage et al. 2019). The last can aid the flow to overcome the coastal density threshold to go hyperpycnal, or can decrease the power of the buoyant plume to carry suspended sediments basinward. On the other hand, the sediment concentration of river discharges can vary significantly between different floods and along time within the same flood. Continuous changes in the properties of the receiving water body and incoming flow parameters could result in different delta types coexisting within a given depositional system (Fig. 4, Tables 1 and 2).

A very common (and at present poorly considered) type of delta in the rock record corresponds to HLD's generated when dirty rivers enter a brackish or a normal salinity marine basin. Due to their extreme low depositional gradient, the resultant deposits typically define 
coarsening-upward successions that are often simply interpreted as "parasequences" (Van Wagoner et al. 1988). Nevertheless, these progradational cycles are controlled by sediment supply (allocycles) and eventually delta shift (autocyclic) instead of only high-frequency sea-level changes. Probably, a number of ancient HLD deposits have been wrongly interpreted as simple shoreface deposits related to the progradation of strandplains. The distinction between weak and strong plunging jets (and associated hyperpycnal plumes) is fundamental to properly understand the characteristics and variability of hyperpycnal deposits in lacustrine and marine settings. Our understanding of these deposits and their associated sequence stratigraphic framework is still very poor and will require further studies.

\begin{abstract}
Abbreviations
PSU: Practical salinity units; $\mathrm{HJ}$ : Hydraulic jump; $\rho_{r}$ : Bulk density of river inflow; $\rho_{\text {rw: }}$ Density of interstitial water in river inflow; $\rho_{w}$ : Density of water in the reservoir; $\Delta \rho_{b}$ : Differential buoyancy; $\Delta \rho / \rho$ : Fractional density difference; $R_{t}$ : Fractional density difference; $R$ : Non-dimensional density parameter; $R_{c}$ : Critical value for a non-dimensional density parameter; CDF: Cohesive debris flow; HCF: Hyperconcentrated flow; CF: Concentrated flow; SLTF: Sediment-laden turbulent flow; SF: Stream flow; HSLD: Hypersaline Littoral Deltas; MLD: Marine Littoral Deltas; BLD: Brackish Littoral Deltas; HOLD: Homopycnal Littoral Deltas; HLD: Hyperpycnal Littoral Deltas; HSD: Hyperpycnal Subaqueous Deltas; HFD: Hyperpycnal Fan-deltas; FSST: Falling Stage Systems Tract; LST: Lowstand Systems Tract; HST: Highstand Systems Tract; ssl: Shelfal sandstone lobes; MTC: Masstransport complex; TSF: Transient fan
\end{abstract}

\section{Acknowledgements}

The authors acknowledge the continuous support provided by the Departamento de Geologia de la Universidad Nacional del Sur and the CONICET (National Research Council from Argentina). We deeply acknowledge the comments, suggestions and positive criticism provided by the three anonymous reviewers, which have been very helpful in improving the manuscript.

\section{Authors' contributions}

$\mathrm{CZ}$ proposed the main idea and wrote the manuscript. MA, MDM and AZ provided a fundamental support in the discussion of the proposed delta classification and design of the figures. GO, Al and AT actively discussed the origin and controls of deltaic sedimentation. All authors read and approved the final manuscript.

\section{Funding}

Not applicable.

Availability of data and materials

Not applicable.

\section{Declarations}

\section{Competing interests}

The authors declare that they have no competing interests.

\section{Author details}

'Dpto. de Geología, Universidad Nacional del Sur (UNS), Bahía Blanca, Argentina. ${ }^{2}$ GCS Argentina SRL, Molina Campos 150, 8000 Bahía Blanca, Argentina. ${ }^{3}$ Consejo Nacional de Investigaciones Científicas y Técnicas, (CONICET), Buenos Aires, Argentina.
Received: 11 February 2021 Accepted: 14 June 2021

Published online: 06 August 2021

\section{References}

Allen, G.P., and F. Mercier. 1987. Les deltas: Sédimentologie et exploration pétrolière. Bulletin de la Société Géologique de France 8 (7): 1247-1269.

Bagnold, R.A. 1962. Auto-suspension of transported sediment: Turbidity currents. Proceedings of the Royal Society of London A265: 315-319.

Barrell, J. 1912. Criteria for the recognition of ancient delta deposits. Geological Society of America Bulletin 23 (1): 377-446. https://doi.org/1 0.1130/GSAB-23-377.

Bates, C. 1953. Rational theory of delta formation. American Association of Petroleum Geologists Bulletin 37: 2119-2162.

Baudin, F., C. Rabouille, and B. Dennielou. 2020. Routing of terrestrial organic matter from the Congo River to the ultimate sink in the abyss: a mass balance approach (André Dumont medallist lecture 2017). Geologica Belgica 23 (1-2): 41-52. https://doi.org/10.20341/gb.2020.004.

Baudin, F., E. Stetten, J. Schnyder, K. Charlier, P. Martinez, B. Dennielou, and L. Droz. 2017. Origin and distribution of the organic matter in the distal lobe of the Congo deep-sea fan - A rock-eval survey. Deep Sea Research Part Il: Topical Studies in Oceanography 142: 75-90. https://doi.org/10.101 6/j.dsr2.2017.01.008.

Bell, C.M. 2009. Quaternary lacustrine braid deltas on Lake general Carrera in southern Chile. Andean Geology 36 (1): 51-65.

Bhattacharya, J.P., and J.A. MacEachern. 2009. Hyperpycnal rivers and prodeltaic shelves in the cretaceous seaway of North America. Journal of Sedimentary Research 79 (4): 184-209. https://doi.org/1 0.2110/jsr.2009.026.

Bourget, J., S. Zaragosi, T. Mulder, J.L. Schneider, T. Garlan, A. Van Toer, V. Mas, and N. Ellouz-Zimmermann. 2010. Hyperpycnal-fed turbidite lobe architecture and recent sedimentary processes: A case study from the Al Batha turbidite system, Oman margin. Sedimentary Geology 229 (3): 144-159. https://doi.org/10.1016/j.sedgeo.2009.03.009.

Breda, A., D. Mellere, and F. Massari. 2007. Facies and processes in a Gilbertdelta-filled incised valley (Pliocene of Ventimiglia, NW Italy). Sedimentary Geology 200 (1-2): 31-55. https://doi.org/10.1016/j.sedgeo.2007.02.008.

Cantelli, A., S. Johnson, J.D.L. White, and G. Parker. 2008. Sediment sorting in the deposits of turbidity currents created by experimental modeling of explosive subaqueous eruptions. The Journal of Geology 116 (1): 76-93. https://doi.org/10.1086/524676.

Catuneanu, O., V. Abreu, J.P. Bhattacharya, M.D. Blum, R.W. Dalrymple, P. G. Eriksson, C.R. Fielding, W.L. Fisher, W.E. Galloway, M.R. Gigbling, K. A. Giles, J.M. Holbrook, R. Jordan, C.G. Kendall, B. Marcuda, O.J. Martinsen, A.D. Miall, J.E. Neal, D. Nummedal, L. Pomar, H.W. Posamentier, B.R. Pratt, J.F. Sarg, K.W. Shanley, R.J. Steel, A. Strasser, M.E. Tucker, and C. Winker. 2009. Towards the standardization of sequence stratigraphy. Earth-Science Reviews 92 (1-2): 1-33. https:// doi.org/10.1016/j.earscirev.2008.10.003.

Colella, A., P.L. De Boer, and S.D. Nio. 1987. Sedimentology of a marine intermontane Pleistocene Gilbert-type fan-delta complex in the Crati Basin, Calabria, southern Italy. Sedimentology 34 (4): 721-736. https://doi. org/10.1111/j.1365-3091.1987.tb00798.x.

Coleman, J.M., and S.M. Gagliano. 1965. Sedimentary structures: Mississippi River deltaic plain. In Primary sedimentary structures and their hydrodynamic interpretation, ed. G.V. Middleton, vol. 12, 133-148. AAPG Special Publications.

Coleman, J.M., and D.B. Prior. 1982. Deltaic environments. In Sandstone depositional environments, ed. P.A. Scholle and D.R. Spearing, vol. 31, 139-178. AAPG Memoir. Tulsa.

Coleman, J.M., and L.D. Wright. 1975. Modern river deltas: Variability of processes and sand bodies. In Deltas - Models for exploration, ed. M.L. Broussard, 99-149. Houston: Houston Geological Society. Tulsa.

Conrad, C., S.W. Dech, M. Hafeez, J.P.A. Lamers, and B. Tischbein. 2013. Remote sensing and hydrological measurement based irrigation performance assessments in the upper Amu Darya Delta, Central Asia. Physics and Chemistry of the Earth, Parts A/B/C 61-62: 52-62. https://doi. org/10.1016/j.pce.2013.05.002 ISSN 1474-7065. 
Cummings, D.I., R.W. Dalrymple, K. Choi, and J.H. Jin. 2015. The tidedominated Han River Delta, Korea: Geomorphology, sedimentology, and stratigraphic architecture, 376. Amsterdam: Elsevier.

Curray, J.R., F.J. Emmel, and D.G. Moore. 2002. The Bengal fan: Morphology, geometry, stratigraphy, history and processes. Marine and Petroleum Geology 19 (10): 1191-1223. https://doi.org/10.1016/ s0264-8172(03)00035-7.

Deville, E., A. Mascle, Y. Callec, P. Huyghe, S. Lallemant, O. Lerat, X. Mathieu, C. Padron de Carillo, M. Patriat, T. Pichot, B. Loubrieux, and D. Granjeon. 2015. Tectonics and sedimentation interactions in the East Caribbean subduction zone: An overview from the Orinoco delta and the Barbados accretionary prism. Marine and Petroleum Geology 64: 76-103. https://doi.org/10.1016/j.marpetgeo.2014.12.015.

Elliot, T. 1986. Deltas. In Sedimentary environments and facies, ed. H.G. Reading, 113-154. Oxford: Blackwell Scientific Publications.

Fischer, H.B., J.E. List, C.R. Koh, J. Imberger, and N.H. Brooks. 1979. Mixing in inland and coastal Waters, 483. New York: Academic Press.

Fisher, W.L., L.F. Brown Jr., A.J. Scott, and J.H. McGowen. 1969. Delta systems in the exploration of oil and gas, 212. Bureau of Economic Geology, University of Texas. Austin, Texas.

Fisk, H.N. 1944. Geological Investigation of the Alluvial Valley of the Lower Mississippi River. In US Corps of Engineers, Mississippi River Commission, 78. Vicksburg: 33 plates.

Fisk, H.N., E. McFarlan Jr., C.R. Kolb, L.J. Wilbert Jr. 1954. Sedimentary framework of the modern Mississippi delta. Journal of Sedimentary Petrology 24: 76-99, 2, https://doi.org/10.1306/D4269661-2B26-11D7-864 8000102C1865D.

Flood, R.D., and D.J.W. Piper. 1997. Amazon fan sedimentation: The relationship to equatorial climate change, continental denudation, and sea-level fluctuations. Proceeding of the Ocean Drilling Program, Scientific Results 155: 653-675.

Flores, R.M. 1990. Transverse and longitudinal gilbert-type deltas, Tertiary Coalmont formation, North Park basin, Colorado, USA. In Coarse grained deltas, ed. A. Colella and D.B. Prior, vol. 10, 223-233. International Association of Sedimentologists Special Publication. Blackwell, London. https://doi.org/10.1002/9781444303858.ch12

Galloway, W.E. 1975. Process framework for describing the morphologic and stratigraphic evolution of deltaic depositional systems. In Deltas -Models for Exploration, ed. M.L. Broussard, 87-98. Houston: Houston Geological Society.

Gani, M.R., and J.P. Bhattacharya. 2005. Lithostratigraphy versus chronostratigraphy in facies correlations of Quaternary deltas: Application of bedding correlation. In River Deltas: Concepts, Models, and Examples, ed. J.P. Bhattacharya and L. Giosan, vol. 83, 31-48. SEPM Special Publications. Tulsa.

Gao, W., G. Li, X. Wang, T. Sun, Y. Liu, and L. Cao. 2014. Sedimentary characteristics of the hyperpycnal flow in the modern Yellow River Delta. Indian Journal of Geo-Marine Sciences 43 (8): 1438-1448.

Gao, W., S. Liu, J. Liu, Y. Xu, and P. Li. 2018. The sedimentary facies and dynamic environment of the Diaokou lobe in the modern Huanghe River Delta of China. Acta Oceanologica Sinica 37 (11): 40-52. https://doi. org/10.1007/s13131-018-1332-z.

Gilbert, G.K. 1885. The topographic features of lake shores. US Geological Survey Annual Report 5: 69-123.

Griggs, G.B., L.D. Kulm, A.C. Waters, and G.A. Fowler. 1970. Deep-sea gravel from Cascadia channel. The Journal of Geology 78 (5): 611-619. https:// doi.org/10.1086/627560

Hage, S., M.J.B. Cartigny, E.J. Sumner, M.A. Clare, J.E. Hughes Clarke, P.J. Talling, D.G. Lintern, S.M. Simmons, R.S. Jacinto, A.J. Vellinga, J.R. Allin, M. Azpiroz-Zabala, J.A. Gales, L. Jamie, J.L. Hizzett, J.E. Hunt, A. Mozzato, D.R. Parsons, E.L. Pope, C.D. Stacey, W.O. Symons, M.E. Vardy, and C. Watts. 2019. Direct monitoring reveals initiation of turbidity currents from extremely dilute river plumes. Geophysical Research Letters 46 (20): 11310-11320. https://doi.org/10.1029/2019GL084526.

Hoyal, D.C.J.D., J.C. Van Wagoner, N.L. Adair, M. Deffenbaugh, D. Li, T. Sun, C. Huh, and D.E. Griffin. 2003. Sedimentation from jets: A depositional model for clastic deposits of all scales and environments. In Search and discovery article 40082 (online-journal; AAPG/Datapages, Inc., 1444 South Boulder, Tulsa, OK, 74119, USA).

Inbar, M. 1987. Effects of a high magnitude flood in a Mediterranean climate: A case study in the Jordan River basin. In Catastrophic Flooding, ed. L. Mayerand and D. Nash, 333-353. London: Allen and Unwin.

Irastorza, A., C. Zavala, M. Irastorza, and M. Turienzo. 2018. Depósitos de prodelta en el Miembro Agua de la Mula (Hauteriviano Tardio Barremiano Temprano), Formación Agrio, Cuenca Neuquina. In 16 Reunión Argentina de Sedimentología, Actas: 158, General Roca.

Jervey, M.T. 1988. Quantitative geological modeling of siliciclastic rock sequences and their seismic expression. In Sea-Level Changes: An Integrated Approach, ed. C.K. Wilgus, B.S. Hasting, C.G.St.C. Kendall, H.W Posamentier, C.A. Ross, and J.C. Van Wagoner, vol. 42, 47-69. Tulsa: Society of Economic Paleontologists and Mineralogists, Special Publication.

Khripounoff, A., A. Vangriesheim, N. Babonneau, P. Crassous, B. Dennielou, and B. Savoye. 2003. Direct observation of intense turbidity current activity in the Zaire submarine valley at $4000 \mathrm{~m}$ water depth. Marine Geology 194 (3-4): 151-158. https://doi.org/10.1016/S0025-3227(02 )00677-1.

Kim, S.A., ed. 2001. Discharge of Buoyant Fluid Jets and Particle-Laden Jets into Stratified Ambient Fluid, 164. Ph.D. thesis, University of British Columbia. Vancouver.

Kuehl, S.A., B.M. Levy, W.S. Moore, and M.A. Allison. 1997. Subaqueous delta of the Ganges-Brahmaputra river system. Marine Geology 144 (1-3): 8196. https://doi.org/10.1016/s0025-3227(97)00075-3.

Lamb, M.P., P.M. Myrow, C. Lukens, K. Houck, and J. Strauss. 2008. Deposits from wave-influenced turbidity currents: Pennsylvanian Minturn formation, Colorado, U.S.A. Journal of Sedimentary Research 78 (7): 480498. https://doi.org/10.2110/jsr.2008.052.

Lee, H., V. Galy, X. Fend, C. Ponton, A. Galy, C. France-Lanord, and S.J. Feakins. 2019. Sustained wood burial in the Bengal fan over the last 19 my. Proceedings of the National Academy of Sciences of the United States of America 116 (45): 22,518-22,525. https://doi.org/10.1073/pnas.1913 714116.

Lin, W., and J.P. Bhattacharya. 2020. Storm-flood-dominated delta: A new type of delta in stormy oceans. Sedimentology 68 (3): 1109-1136. https://doi.org/10.1111/sed.12819.

Liu, J.T., S.J. Kao, C.A. Huh, and C.C. Hung. 2013. Gravity flows associated with flood events and carbon burial: Taiwan as instructional source area. Annual Review of Marine Science 5 (1): 47-68. https://doi.org/10.1146/a nnurev-marine-121211-172307.

Luo, Z., J. Zhu, H. Wu, and X. Li. 2017. Dynamics of the sediment plume over the Yangtze Bank in the Yellow and East China Seas: Journal of Geophysical Research: Oceans 122 (12): 10,073-10,090. https://doi.org/1 0.1002/2017JC013215.

Macquaker, J.H.S., S.J. Bentley, and K.M. Bohacs. 2010. Wave-enhanced sediment gravity flows and mud dispersal across continental shelves: Reappraising sediment transport processes operating in ancient mudstone successions. Geology 38 (10): 947-950. https://doi.org/10.113 0/G31093.1.

Marcomini, S.C., A. Tripaldi, P. Leal, R.A. López, M.S. Alonso, P. Ciccioli, A. Quesada, and P. Bunicontro. 2018. Morfodinámica y sedimentación de un sector del frente deltaico del Paraná (1933-2016), Provincia de Buenos Aires, Argentina. Revista de la Asociación Geológica Argentina 75: 1-16.

Miall, A.D. 1984. Deltas. In Facies Models, Geoscience Canada Reprint Series 1, ed. R.G. Walker, 2nd ed., 105-118.

Mulder, T., and J.P.M. Syvitski. 1995. Turbidity currents generated at river mouths during exceptional discharges to the world oceans. Journal of Geology 103 (3): 285-299. https://doi.org/10.1086/629747.

Mulder, T., J.P.M. Syvitski, S. Migeon, J.C. Faugéres, and B. Savoye. 2003. Marine hyperpycnal flows: Initiation, behavior and related deposits. A review. Marine and Petroleum Geology 20 (6-8): 861-882. https://doi. org/10.1016/..marpetgeo.2003.01.003.

Mutti, E., G. Davoli, R. Tinterri, and C. Zavala. 1996. The importance of ancient fluvio-deltaic systems dominated by catastrophic flooding in 
tectonically active basins. Memorie di Scienze Geologiche, Universita di Padova 48: 233-291.

Mutti, E., R. Tinterri, G. Benevelli, D. Di Biase, and G. Cavanna. 2003. Deltaic, mixed and turbidite sedimentation of ancient foreland basins. Marine and Petroleum Geology 20 (6-8): 733-755. https://doi.org/10.1016/j.ma rpetgeo.2003.09.001.

Nakajima, T. 2006. Hyperpycnites deposited $700 \mathrm{~km}$ away from river mouths in the Central Japan Sea. Journal of Sedimentary Research 76 (1): 59-72.

Nemec, W. 1990. Aspects of sediment movement on steep delta slope. In Coarse-grained deltas, ed. A. Colella and D.B. Prior, vol. 10, 29-73. International Association of Sedimentologists Special Publication. https://doi.org/10.1002/9781444303858.ch3.

Nemec, W. 1995. The dynamics of deltaic suspension plumes. In Geology of Deltas, ed. M.N. Oti and G. Postma, 31-93. Rotterdam: A.A., Balkema.

Nittrouer, C.A., S.A. Kuehl, D.J. Demaster, and R.O. Kowsmann. 1986. The deltaic nature of Amazon shelf sedimentation. Geological Society of America Bulletin 97 (4): 444-458. https://doi.org/10.1130/0016-7606(1 986) $97<444: T D N O A S>2.0 . C O ; 2$

Oceanlife Water Salinity Converter 2017. https://www.oceanlife.it/index.php/ en/19-notizie/370-water-salinity-converter-en. Last Accessed 1/7/2021.

Orton, G.J., and H.G. Reading. 1993. Variability of deltaic processes in terms of sediment supply, with particular emphasis on grain size. Sedimentology 40 (3): 475-512. https://doi.org/10.1111/j.1365-3091.1993.tb01347.x.

Overeem, I., S.B. Kroonenberg, and A. Veldkamp. 2003. Small-scale stratigraphy in a large ramp delta: Recent and Holocene sedimentation in the Volga delta, Caspian Sea. Sedimentary Geology 159 (3-4): 133-157. https://doi.org/10.1016/S0037-0738(02)00256-7.

Paim, P.S.G., E.L.C. Lavina, U.F. Faccini, A.S. Da Silveira, H.A. Leanza, and R.S.F. D'Avila. 2011. Fluvial-derived turbidites in the Los Molles formation (Jurassic of the Neuquén Basin): Initiation, transport, and deposition. In Sediment Transfer from Shelf to Deep Water - Revisiting the Delivery System, ed. R.M. Slatt and C. Zavala, vol. 61, 95-116. Tulsa: AAPG Studies in Geology.

Panin, N., L. Tiron Dutu, and F. Dutu. 2016. The Danube delta: An overview of its Holocene evolution. Méditerranée 126: 37-54.

Parsons, J.R., J.W.M. Bush, and J.P.M. Syvitski. 2001. Hyperpycnal plume formation from riverine outflows with small sediment concentrations. Sedimentology 48 (2): 465-478. https://doi.org/10.1046/j.1365-3091.2001. 00384.x.

Petersen, S.V., C.R. Tabor, K.C. Lohmann, C.J. Poulsen, K.W. Meyer, S.J. Carpenter, J.M. Erickson, K.K.S. Matsunaga, S.Y. Smith, and N.D. Sheldon. 2016. Temperature and salinity of the Late Cretaceous Western interior seaway. Geology 44 (11): 903-906. https://doi.org/10.1130/G38311.1.

Plint, A.G. 2013. Mud dispersal across a cretaceous prodelta: Stormgenerated, wave-enhanced sediment gravity flows inferred from mudstone microtexture and microfacies. Sedimentology 61: 609-647.

Postma, G., and T.B. Roep. 1985. Resedimented conglomerates in the bottomsets of Gilbert-type gravel deltas. Journal of Sedimentary Research 55: 874-885.

Prior, D.B., and B.D. Bornhold. 1990. The underwater development of Holocene fan deltas. In Coarse-grained deltas, ed. A. Colella and D.B. Prior, vol. 10, 75-90. International Association of Sedimentologists Special Publication. Blackwell, London. https://doi.org/10.1002/97814443 03858.ch4

Pritchard, D., and C. Gladstone. 2009. Reversing buoyancy inturbidity currents: Developing a hypothesis for flow transformation and for deposit facies and architecture. Marine and Petroleum Geology 26 (10): 1997-2010. https://doi.org/10.1016/j.marpetgeo.2009.02.010.

Rajchl, M., D. Uličný, and K. Mach. 2008. Interplay between tectonics and compaction in a rift-margin, lacustrine delta system: Miocene of the Eger graben, Czech Republic. Sedimentology 55 (5): 1419-1447. https:// doi.org/10.1111/j.1365-3091.2008.00951.x

Schieber, J. 2016. Mud re-distribution in epicontinental basins - exploring likely processes. Marine and Petroleum Geology 71: 119-133. https://doi. org/10.1016/.jmarpetgeo.2015.12.014.

Shanmugam, G. 2018. The hyperpycnite problem. Journal of Palaeogeography 7 (3): 6. https://doi.org/10.1186/s42501-018-0001-7.
Simpson, J.E. 1982. Gravity currents in the laboratory, atmosphere, and ocean. Annual Review of Fluid Mechanics 14 (1): 213-234. https://doi. org/10.1146/annurev.fl.14.010182.001241.

Smith, D., and H. JOL. 1997. Radar structure of a Gilbert-type delta, Peyto Lake, Banff National Park, Canada. Sedimentary Geology 113 (3-4): 195209. https://doi.org/10.1016/S0037-0738(97)00061-4.

Sparks, R.S.J., R.T. Bonnecaze, H.E. Huppert, J.R. Lister, M.A. Hallworth, H. Mader, and J. Phillips. 1993. Sediment-laden gravity currents with reversing buoyancy. Earth and Planetary Science Letters 114 (2-3): 243257. https://doi.org/10.1016/0012-821X(93)90028-8.

Turner, J.S., and H.E. Huppert. 1992. Sedimentation and mixing at the top of a suspended particles. In Proceedings of the $11^{\text {th }}$ Australian Fluid Mechanics Conference, 747-750. Hobart: University of Tasmania.

Van Wagoner, J.C., H.W. Posamentier, R.M. Mitchum, P.R. Vail, J.F. Sarg, T.S. Loutit, and J. Hardenbol. 1988. An overview of sequence stratigraphy and key definitions. In Sea level changes-An Integrated Approach, ed. C.K. Wilgus, B.S. Hastings, C.G.St.C. Kendall, H.W. Posamentier, C.A. Ross, and J.C. Van Wagoner, vol. 42, 39-45. SEPM Special Publication. Tulsa. https://doi.org/10.2110/pec.88.01.0039.

Violante, C. 2009. Rocky coast: Geological constraints for hazard assessment In Geohazard in Rocky Coastal Areas. The Geological Society of London, Special Publications, ed. C. Violante, vol. 322, 1-31.

Violante, C., G.C. Braca, E. Esposito, and G. Tranfaglia. 2016. The 9 September 2010 torrential rain and flash flood in the Dragone catchment, Atrani, Amalfi coast (southern Italy). Natural Hazards and Earth System Sciences 16 (2): 333-348. https://doi.org/10.5194/nhess-16-333-2016.

Wang, H., Z. Yang, G. Li, and W. Jiang. 2006. Wave climate modeling on the abandoned Huanghe (Yellow River) delta lobe and related deltaic erosion. Journal of Coastal Research 22 (4): 906-918.

Westman, P., S. Wastegård, K. Schoning, B. Gustafsson, and A. Omstedt 1999. Salinity change in the Baltic Sea during the last 8,500 years: Evidence, causes and models. In Swedish Nuclear Fuel and Waste Management Company, Technical Report TR-- 99-38, 1-47.

Wilcox, A.C., C. Escauriaza, R. Agredano, E. Mignot, V. Zuazo, S. Otárola, L. Castro, J. Gironás, R. Cienfuegos, and L. Mao. 2016. An integrated analysis of the march 2015 Atacama floods. Geophysical Research Letters 43 (15): 8035-8043. https://doi.org/10.1002/2016GL069751.

Wilson, R., and J. Schieber. 2014. Muddy prodeltaic hyperpycnites in the lower Genesee Group of Central New York, USA: Implications for mud transport in epicontinental seas. Journal of Sedimentary Research 84 (10): 866-874. https://doi.org/10.2110/jsr.2014.70.

Wilson, R., and J. Schieber. 2017. Association between wave- and currentaided hyperpycnites and flooding surfaces in shelfal mudstones: An integrated sedimentologic, sequence stratigraphic, and geochemical approach. Journal of Sedimentary Research 87 (11): 1143-1155. https:// doi.org/10.2110/jsr.2017.62.

Winsemann, J., J. Lang, U. Polom, M. Loewer, J. Igel, L. Pollock, and C. Brandes. 2018. Ice-marginal forced regressive deltas in glacial lake basins: Geomorphology, facies variability and large-scale depositional architecture. Boreas 47 (4): 973-1002. https://doi.org/10.1111/bor.12317.

Yang, Z.S., and J.P. Liu. 2007. A unique Yellow River-derived distal subaqueous delta in the Yellow Sea. Marine Geology 240 (1-4): 169-176. https://doi.org/10.1016/j.margeo.2007.02.008.

Zavala, C. 2020. Hyperpycnal flows and deposits. Journal of Palaeogeography 9 (1): 1-21. https://doi.org/10.1186/s42501-020-00065-x.

Zavala, C., and M. Arcuri. 2016. Intrabasinal and extrabasinal turbidites: Origin and distinctive characteristics. Sedimentary Geology 337: 36-54. https://doi.org/10.1016/j.sedgeo.2016.03.008.

Zavala, C., M. Arcuri, M. Di Meglio, A. Zorzano, V.H. Goitia Antezana, and L.R. Arnez Espinosa. 2016. Prodelta hyperpycnites: Facies, processes and resenvoir significance. Examples from the Lower Cretaceous of Russia, 73-73. Barcelona: International Conference and Exhibition https:/doi.org/10.1190/ice2016-6356637.1.

Zavala, C., M. Arcuri, H. Gamero, C. Contreras, and M. Di Meglio. 2011. A genetic facies tract for the analysis of sustained hyperpycnal flow deposits. In Sediment Transfer from Shelf to Deep Water - Revisiting the Delivery System, ed. R.M. Slatt and C. Zavala, vol. 61, 31-51. AAPG Studies in Geology. Tulsa. 
Zavala, C., M. Arcuri, and L. Blanco Valiente. 2012. Plant remains in recent deposits of the Orinoco fan: a direct evidence of hyperpycnal discharges of the Orinoco River. In GSTT $5^{\text {th }}$ Geological Conference 2012. Trinidad \& Tobago: Hilton Hotel \& Conference Centre September 3-5 2012.

Zavala, C., L. Blanco Valiente, and Y. Vallez. 2008. The origin of lofting rhythmites. Lessons from thin sections. AAPG Hedberg Conference "Sediment Transfer from Shelf to Deepwater - Revisiting the Delivery Mechanisms". March 3-7, 2008-Ushuaia-Patagonia, Argentina . AAPG Search and Discovery Article \#50077, Posted May 15, 2008. http://www. searchanddiscovery.com/pdfz/documents/2008/jw0807zavala/images/ jw0807zavala.pdf.html.

Zavala, C., X.B. Li, H.Q. Liu, M. Arcuri, M. Di Meglio, A. Zorzano, G. Otharán, B. $\mathrm{HaO}$, and $Y$. Wang. In press. Lacustrine sequence stratigraphy: New insights from the study of the Yanchang Formation (Middle-Late Triassic), Ordos Basin, China. In The Ordos Basin, ed. R.C. Yang and A.J. Van Loon. 2021. Elsevier.

Zavala, C., and S.X. Pan. 2018. Hyperpycnal flows and hyperpycnites: Origin and distinctive characteristics. Lithologic Reservoirs 30 (1): 1-27.

Zavala, C., J. Ponce, D. Drittanti, M. Arcuri, H. Freije, and M. Asensio. 2006. Ancient lacustrine hyperpycnites: A depositional model from a case study in the Rayoso Formation (Cretaceous) of West-Central Argentina. Journal of Sedimentary Research 76 (1): 41-59. https://doi.org/10.2110/ jsr.2006.12.

\section{Publisher's Note}

Springer Nature remains neutral with regard to jurisdictional claims in published maps and institutional affiliations.

\section{Submit your manuscript to a SpringerOpen ${ }^{\circ}$ journal and benefit from:}

- Convenient online submission

- Rigorous peer review

- Open access: articles freely available online

High visibility within the field

- Retaining the copyright to your article

Submit your next manuscript at $\boldsymbol{\nabla}$ springeropen.com 